\title{
Medium-term acclimation of feeding and of digestive and metabolic enzyme activity in the neritic copepod Acartia clausi. I. Evidence from laboratory experiments
}

\author{
O. Roche-Mayzaud ${ }^{1}$, P. Mayzaud ${ }^{1}$, D. C. Biggs ${ }^{2}$ \\ ${ }^{1}$ INRS-Océanologie, 310 Allée des Ursulines, Rimouski, Québec, Canada G5L 3A1 \\ ${ }^{2}$ Department of Oceanography, Texas A and M University, College Station, Texas 77843, USA
}

\begin{abstract}
The time-relationship between food supply, intermediate metabolism (ETS, GDH activities) and nutritional processes (ingestion, digestive enzyme activities) was established experimentally for the small neritic copepod Acartia clausi. In the first 3 experiments, food-limiting conditions (suboptimal growth) were imposed and the food supply simulated: (1) different concentrations of a single pulse of phytoplankton; (2) different declining phytoplankton concentrations; or (3) a double pulse of phytoplankton. In all 3 cases positive acclimation of ingestion rates and digestive enzyme activities (amylase, laminarinase and trypsin) was observed. Trypsin appeared to have a low threshold of sensitivity to food changes suggesting that the copepods may enhance their potential for protein digestion at low food concentrations. In the fourth experiment we confirmed that under saturating food concentrations, copepods showed increased food intake and intermediate metabolism but no acclimation of their digestive enzyme systems. Except during starvation, day-to-day patterns of ETS and GDH activities did not covary with food quantity, although ETS varied with food quality and food type. Contradictions between previously published and present results are discussed and confirm that the time acclimation hypothesis of Mayzaud \& Poulet (1978; Limnol. Oceanogr. 23: 1144-1154) applies only for food-limiting conditions. Under the present experimental conditions, A. clausi appeared to require $48 \mathrm{~h}$ to significantly acclimate to changes in food ration exceeding a threshold of 1.5 to $2 \mu \mathrm{gC}$ ind. ${ }^{-1}$. The time acclimation hypothesis should be revised to emphasize that nutrition is likely controlled by feedback mechanisms which operate to meet the metabolic requirements of individuals and that acclimation of the different aspects of nutrition (ingestion and digestion) take place over different time scales.
\end{abstract}

\section{INTRODUCTION}

The concept of time acclimation of the nutritional processes in zooplankton was introduced by Mayzaud \& Poulet (1978) in order to explain the apparent seasonal covariation of the particulate potential food supply with the ingestion rate and the digestive enzyme activity of small neritic copepods. They proposed that under natural, food-limiting conditions (i.e. suboptimal growth), ingestion rates should follow more or less the changes in food standing stock and that digestion rate should positively track changes in food quantity as long as the qualitative characteristics of the food-intake remained constant.

Although primarily defined for small neritic copepods, the concept was extended by various authors to other groups of copepods. Linear relationships between ingestion rates and food concentration were described in several studies (Reeve \& Walter 1977, Conover 1978, Koeller et al. 1979, Huntley 1981, Uye \& Kasahara 1983, Conover \& Mayzaud 1984) but not found in recent reports by Paffenhöfer \& Van Sant (1985) and Ayukai (1987). Similarly, positive acclimation of digestive enzymes (i.e. increase in enzyme activity in agreement with the food ingested) was observed in several studies (cf. review by Mayzaud 1986), confirmed experimentally (Boucher et al. 1976, Cox 1981, Hirche 1981, Cox \& Willasson 1981) and recently disputed by Hassett \& Landry $(1983,1988)$, Landry \& Hassett (1985), Harris et al. (1986) and Båmstedt (1988).

The overall contradiction among published results 
seems to have originated from: (1) the failure by various authors to reproduce in the laboratory the field conditions in which time acclimation occurs and (2) attempts to compare experimental results which are not strictly comparable. Moreover, most experimental studies have not recognized that the ultimate control of nutritional acclimation is not food supply but the organism's energy requirements.

In the present study, we have tried to: (1) clarify the nature of the ingestive and digestive response to medium term (days) food changes of small neritic copepods; (2) ascertain experimentally the reality of time acclimation of digestive processes; and (3) relate these nutritional changes to those of the intermediary metabolism as expressed by measurements of the electron transport system (ETS) and glutamate dehydrogenase (GDH) activity.

\section{MATERIALS AND METHODS}

Adults and stage V copepodites of the copepod Acartia clausi were collected from the Bay of Villefranche, France, using a $333 \mu \mathrm{m}$ mesh size net. Water from tow depth was also collected using a Niskin sampler. The copepods were returned to the laboratory within half an hour and sorted immediately according to developmental stages under a binocular microscope. The specimens (females with some CV) were generally acclimated to laboratory conditions overnight in natural sea water at in situ temperature. The diatom Skeletonema costatum was generally used as food, except in Expt 4 where the chrysophyte Hymenomonas elongata was used in combination with the diatom. Samples of adult Acartia clausi were deep-frozen $\left(-70^{\circ} \mathrm{C}\right)$ immediately after capture to determine field level of digestive enzymes (Day 0 condition).

The time dependency of feeding rates, digestive enzyme levels, and ETS and GDH activities in relation to food variation was investigated through initial starvation experiments in filtered seawater, plus 4 different sets of feeding experiments (Expts 1 to 4) during April, May and June 1985. In designing the feeding experiment protocol, care was taken to meet 3 criteria in order to confirm the nature of digestive acclimation: (1) the copepod should be subjected to 2 or more different levels of the same food for a period of several days; (2) as in nature, the food supply should be limiting and variable over time; and (3) the chemical and biochemical composition of the food should be appropriate to the enzyme system examined.

For our initial work, we tracked the daily enzyme activity of 3 groups of copepods that we collected in late winter and held in the laboratory for several days in $0.45 \mu \mathrm{m}$ filtered seawater. Individuals from Group A were subsampled daily for $3 \mathrm{~d}$ after their capture on 18 March 1985; those from Group B for $3 \mathrm{~d}$ after their capture on 19 March; and those from Group C for $4 \mathrm{~d}$ after their capture on 21 March.

Skeletonema costatum or Hymenomonas elongata were grown under a 12:12 h light-dark cycle in ES Provasoli medium. In all 4 experiments, algal batch cultures were initiated every other day and each batch was used as food for 2 consecutive days to provide the copepods with roughly similar-age algae. The experimental food media were prepared by adding known concentrations of phytoplankton batch culture to GF/C filtered seawater. For practical reasons, the seawater was filtered immediately after collection and kept at natural temperature in a cold room until use the next day.

In Expt 1, a set of copepods collected on 1 April (late winter conditions) was divided into 3 groups. Immediately after capture, each group was fed on 1 of 3 different concentrations of Skeletonema costatum: 'High', 14000 cells $\mathrm{ml}^{-1}(2.9 \mathrm{ppm}$ by volume or $\left.1400 \mu \mathrm{gC}^{-1}\right)$; 'Medium', 7000 cells $\mathrm{ml}^{-1}(1.5 \mathrm{ppm}$ by volume or $700 \mu \mathrm{gC} \mathrm{1}^{-1}$ ); or 'Low', 1500 cells $\mathrm{ml}^{-1}$ ( $0.7 \mathrm{ppm}$ by volume or $350 \mu \mathrm{gC} \mathrm{l}^{-1}$ ). The experiment attempted to simulate the influence of a single pulse of phytoplankton over $4 \mathrm{~d}$. The culture of $S$. costatum used was in the exponential growth phase and was harvested $5 \mathrm{~d}$ after inoculation $\left(10^{5}\right.$ cells $\left.\mathrm{ml}^{-1}\right)$.

In Expt 2, copepods collected in spring (13 May), were initially acclimated to laboratory conditions in natural seawater for $24 \mathrm{~h}$ before being divided into 3 groups. To simulate an acclimation to decreasing food concentrations, the individuals in the first group were starved throughout the experiment, while the 2 other groups were subjected to 2 different and decreasing concentrations of diatom food initially set at 2 high levels: i.e. 70000 cells ml $^{-1}\left(5600 \mu \mathrm{gC}^{-1}\right)$ and 14000 cells $\mathrm{ml}^{-1}\left(1100 \mu \mathrm{gC}^{-1}\right)$. The culture of Skeletonema costatum used was harvested at the same stage of growth as in the previous experiment.

Expt 3 attempted to simulate the influence of a double pulse of phytoplankton. The first pulse lasted for $24 \mathrm{~h}$ and was separated from the second by a period of $24 \mathrm{~h}$. As previously, copepods collected in late spring (20 May) were acclimated for $24 \mathrm{~h}$ in unfiltered seawater before being divided into 3 groups. One group was starved throughout the $6 \mathrm{~d}$ period and the other 2 supplied on Day 1 with the same 2 concentrations of Skeletonema costatum as in Expt 2. Early stationary growth phase diatom culture was used (i.e. $10 \mathrm{~d}$ after inoculation) in order to potentially optimize the laminarinase response.

Expt 4 was designed to evaluate the influence of alternating limiting/saturating/limiting food conditions on the ingestion-digestion response. After being held 
in the laboratory for $24 \mathrm{~h}$ in natural seawater, copepods collected in early summer (3 June) were fed a limiting diet of Skeletonema costatum for $4 \mathrm{~d}$ at a concentration of 20000 cells $\mathrm{ml}^{-1}\left(1600 \mu \mathrm{gCl}^{-1}\right)$. On the fifth day, one group of individuals was maintained on the same diet while another group was fed on saturating concentrations $\left(40 \mathrm{mgC}^{-1}\right.$ ) of Hymenomonas elongata each day for $3 \mathrm{~d}$. After this latter change of food regime, this group was then returned to the initial diet of $S$. costatum diet for an additional $3 \mathrm{~d}$. The use of 2 different phytoplankters was made necessary because of the impossibility of achieving sufficient volume of batch culture of $S$. costatum to maintain saturating and limiting food conditions at the same time. By the use of a larger-size, better-accepted species of phytoplankton, saturating food concentrations could be obtained with moderate volume of culture without reduced ingestion rates. As we will see later, because digestive enzyme acclimation is governed by concentration rather than nature of food (Head \& Conover 1983, Harris et al. 1986), such an experimental strategy is not likely to confound the interpretation by added variability.

In all experiments, copepod mean density ranged from 300 to 400 Acartia clausi which were placed in 11 jars and attached to a rotating wheel in a constant temperature room under dim light at $18^{\circ} \mathrm{C}$. Concentrations of algal food in each jar were monitored and adjusted daily using a Coulter counter (model TA) during Expts 1 and 2. During Expt 2, a major failure of the Coulter counter led us to use an alternate method. Thus daily monitoring in the subsequent Expts 3 and 4 was done fluorometrically following the standard method introduced by Yentsch \& Menzel (1963) using an Aminco fluorometer. Because of this failure, volumes estimated in Expts 1 and 2 should be considered only on a relative basis. Indeed relationships between cell number, cell carbon and volume suggested a consistent overestimation of the particulate volume by a factor of 5 .

Copepod feeding rates were calculated from changes in food concentrations between sampling times (usually 20 to $24 \mathrm{~h}$ ). Algal growth rates (i.e. grazing controls) were determined from changes in cell densities in samples of food without copepods incubated under similar conditions. Calculations of ingestion were made according to the equation of Frost (1972). Available food supply was expressed on a per individual basis rather than per unit volume to correct for variations $( \pm 20 \%)$ in the initial number of live experimental individuals per jar without corresponding changes in total volume. Indeed, considering the normal filtering rate of adult Acartia clausi and the relatively high copepod densities, a worst case possibility existed that the entire experimental volume would be swept clear making food availability strongly time- and density- dependent. Although concentrations in particles or chlorophyll remaining after each 20 to $24 \mathrm{~h}$ sampling were on average $45 \%$ of the initial values, indicating that this worst case seldom occurred, we of course recognize that a significant fraction of the particulate chlorophyll left could originate from the grazing activity of the copepods (O'Connors et al. 1976). Copepod mortality, at any rate, remained well below $5 \% \mathrm{~d}^{-1}$ in all feeding experiments.

On each sampling day, one jar at each food level was randomly picked and, after removal of dead or moribund copepods, the remainder were counted and then deep-frozen $\left(-0^{\circ} \mathrm{C}\right)$ for subsequent enzyme analyses. The remaining jars were checked for dead individuals and their food medium replaced to the desired concentration. Aliquot samples of phytoplankton cultures were filtered on precombusted Whatman GF/C glass-fibre filters for subsequent analyses (in triplicate) of carbon, nitrogen, protein, total carbohydrates and soluble carbohydrate content per cell. Microscope enumeration of the algal stock-culture density was also carried out to check the growth status of the culture.

Amylase, laminarinase, trypsin and alkaline protease activities were measured on 3 subsamples of 80 and 120 individuals each after homogenization in Tris- $\mathrm{HCl}$ buffer (pH: $7.0 ; 0.05 \mathrm{M}$ ) and centrifugation at $10000 \times g$ and $2^{\circ} \mathrm{C}$. Optimum conditions for measuring amylase and laminarinase activity were previously established with crude extracts and purified enzymes (Mayzaud \& Mayzaud 1981, Roche-Mayzaud 1985, Roche-Mayzaud \& Mayzaud 1987) while optimum conditions for trypsin and alkaline protease activities were established only with crude extracts. Amylase, laminarinase and trypsin activities were measured according to the methods described by Mayzaud (1980) and Mayzaud et al. (1984). Alkaline protease activity was estimated from the hydrolysis of casein-yellow (Calbiochem.) according to the procedure described by Van Wormhoudt (1973). Protein measurements were carried out according to Lowry et al. (1951) using bovine albumin as a standard. Enzyme activity was expressed on a per individual basis because soluble protein concentrations per individual varied seasonally in the Bay of Villefranche, and also generally increased with increasing food supply in our experiments.

Electron transport system (ETS) and glutamate dehydrogenase (GDH) activities were estimated on a fourth subsample of 80 to 120 copepods after homogenization in Tris-acetate buffer ( $\mathrm{pH}$ : 8.6; $0.1 \mathrm{M}$; $0.2 \%$ Triton $\mathrm{X}-100$ ) according to the methodologies described by Bidigare et al. (1982). However, because of the small sample sizes available (only 300 to $500 \mu \mathrm{m}$ soluble protein per 100 individuals), both ETS and $\mathrm{GDH}$ were modified for small-volume analyses $(0.25 \mathrm{ml}$ homogenate and $1.5 \mathrm{ml}$ total reaction volume for ETS; 
$1.4 \mathrm{ml}$ total volume of reaction mixture for $\mathrm{GDH}$, containing $5.4 \mu \mathrm{mol}$ ADP, $3.2 \mu \mathrm{mol}$ NAD, $48 \mu \mathrm{mol}$ glutamate and $100 \mu \mathrm{l}$ enzyme homogenate).

Carbon and nitrogen contents of the experimental phytoplankton were measured with a Perkin-Elmer $\mathrm{CHN}$ analyzer. Total protein and total carbohydrate concentrations were estimated by the methods of Lowry et al. (1951) and Dubois et al. (1956) respectively. Soluble carbohydrate content was measured according to Mayzaud et al. (1985) using a double extraction in $0.05 \mathrm{~N} \mathrm{HCl}$ at $50^{\circ} \mathrm{C}$.

Statistical analyses were performed using SPSS and SYSTAT software packages. Significance of time changes was tested using the non-parametric KruskalWallis test while differences between treatments were compared using both the non-parametric Wilcoxon 2-sample test and the multiple comparison test. Both tests yield identical results.

\section{RESULTS}

\section{Changes in body protein content}

Following Harris et al. (1986), food saturation can be defined, at least to a first approximation, as the concentration of food which sustains maximum body protein content. Although such a definition is somewhat different from that of optimal growth, it follows that under food saturation, body protein content should be high and more or less constant. By corollary, body protein content should change with food concentrations under food-limiting conditions. The data presented in Table 1 summarize how individual protein content varied on dates when the ranges in food supply within each experiment was greatest. As expected for food-limited individual, mean per individual protein content followed the food availability for all 4 experiments with Skeletonema costatum. By contrast, those specimens fed Hymenomonas elongata exhibited nearly identical body protein concentrations confirming that $H$. elongata was a foodsaturating ration.
Table 1. Acartia clausi. Protein content of adult females during the course of the 4 experiments of digestion acclimation. Data are featured from sampling dates on which the maximum range of food concentrations were offered. Starv.: starvation; $\mathrm{SD}$ : standard deviation

\begin{tabular}{|cclc|}
\hline Expt & $\begin{array}{c}\text { Sampling } \\
\text { date }\end{array}$ & Food level & $\begin{array}{c}\text { Protein concentration } \\
\left(\mu \text { ind }^{-1}\right) \pm \mathrm{SD}\end{array}$ \\
\hline 1 & $\mathrm{D}_{4}$ & Low & $1.88 \pm 0.08$ \\
& & Medium & $2.15 \pm 0.19$ \\
& & High & $3.31 \pm 0.13$ \\
2 & $\mathrm{D}_{2}$ & Starv. & $1.63 \pm 0.14$ \\
& & Low & $1.99 \pm 0.07$ \\
3 & & High & $2.91 \pm 0.14$ \\
& $\mathrm{D}_{5}$ & Starv. & $1.86 \pm 0.12$ \\
& & Low & $2.28 \pm 0.01$ \\
4 & & High & $3.09 \pm 0.18$ \\
& & Sk. cost. & $2.28 \pm 0.14$ \\
& & Hymen. & $3.24 \pm 0.10$ \\
& $\mathrm{D}_{7}$ & Sk. cost. & \\
& & Hymen. & $3.22 \pm 0.10$ \\
& $\mathrm{D}_{8}$ & Sk. cost. & $2.70 \pm 0.15$ \\
& & Hymen. & $3.28 \pm 0.21$ \\
\hline
\end{tabular}

\section{Starvation}

Our initial experiment demonstrated that field levels of GDH and ETS activity declined rapidly when copepods were held without food in laboratory aquaria. Fig. 1A, B shows that copepods starved over 2 to $4 \mathrm{~d}$ had GDH and ETS activities less than half those of 'wild' individuals freshly collected from the field. These activities appeared to approach an asymptote of about $5 \pm 2 \mathrm{nmol}$ ind..$^{-1} \mathrm{~h}^{-1}$ for GDH and $10 \pm 2 \mathrm{nmol}^{\mathrm{ind}} \mathrm{.}^{-1}$ $\mathrm{h}^{-1}$ for ETS $(\mathrm{n}=6)$. Throughout the starvation timecourse, however, the ratio ETS/GDH activity remained more or less constant $(2.1 \pm 0.6)$.

\section{Feeding}

In our series of 4 feeding experiments, we also observed that GDH and ETS activities were generally
A

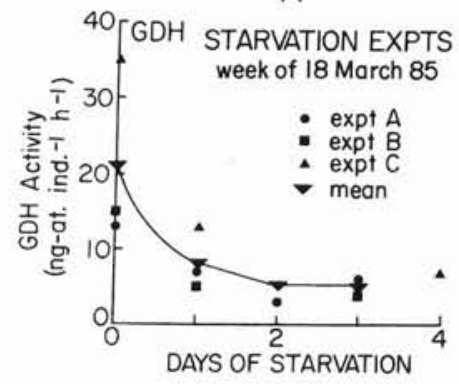

B

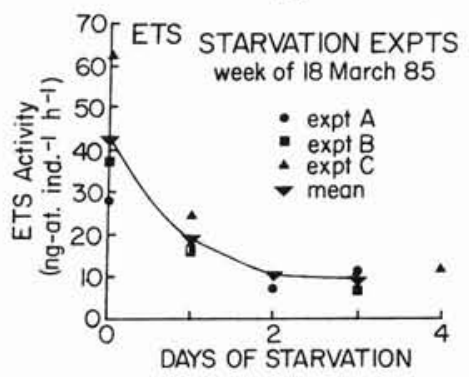

Fig. 1. Acartia clausi. Decrease in ETS and GDH activity for individuals held for 1 to $4 \mathrm{~d}$ without feeding in laboratory aquaria 
lower in copepods held in the laboratory than those freshly collected from the field, although not as low as in those individuals starved for several days. In contrast, as we will describe below, activities of the 3 digestive enzymes usually recovered when the experimental copepods were fed, and in some instances experimental digestive enzyme activity per individual exceeded those of specimens freshly collected from the field.

\section{Expt 1}

The diatom concentrations in our first experiment simulated conditions that copepods might encounter in a spring bloom when they would be exposed for several days to a single pulse of phytoplankton. The 'High', 'Medium' and 'Low' regimes allowed us to contrast 3 different intensities of this 'bloom'. As indicated in Fig. $2 \mathrm{~A}$, each level of concentration was increased by $30 \%$ over the first $2 \mathrm{~d}$ and brought back to the initial value on the last day. Because it was growing in log-phase when harvested for Days 1 and 3, the different batches of culture of Skeletonema costatum used throughout the first experiment did not exhibit large changes in either chemical or biochemical composition. However, by Day 4 the last batch of culture had apparently reached early stationary phase as evidenced by an increase in protein and total carbohydrate content per cell (Table 2). Throughout the experiment, however, the cells of $S$. costatum were characterized by a narrow range in elemental C: $\mathrm{N}$ ratio (5.5 to 6.5$)$ and in protein:carbohydrate : lipid ratio $(5: 3: 1$ to $6: 4: 1)$.

The experimental copepods were subjected to the different food concentrations immediately after capture on 1 April and, except for the first $24 \mathrm{~h}$, displayed a positive functional relationship between ingestion rate and phytoplankton changes (Fig. 2B). A Wilcoxon 2sample test indicated that the responses were significantly different $(\mathrm{p}<0.01)$ for all 3 food levels and could be ranked accordingly: High $>$ Medium $>$ Low. However, the time changes were only significant for the highest food levels (Kruskal-Wallis test; $\mathrm{p}<0.03$ ), sug-
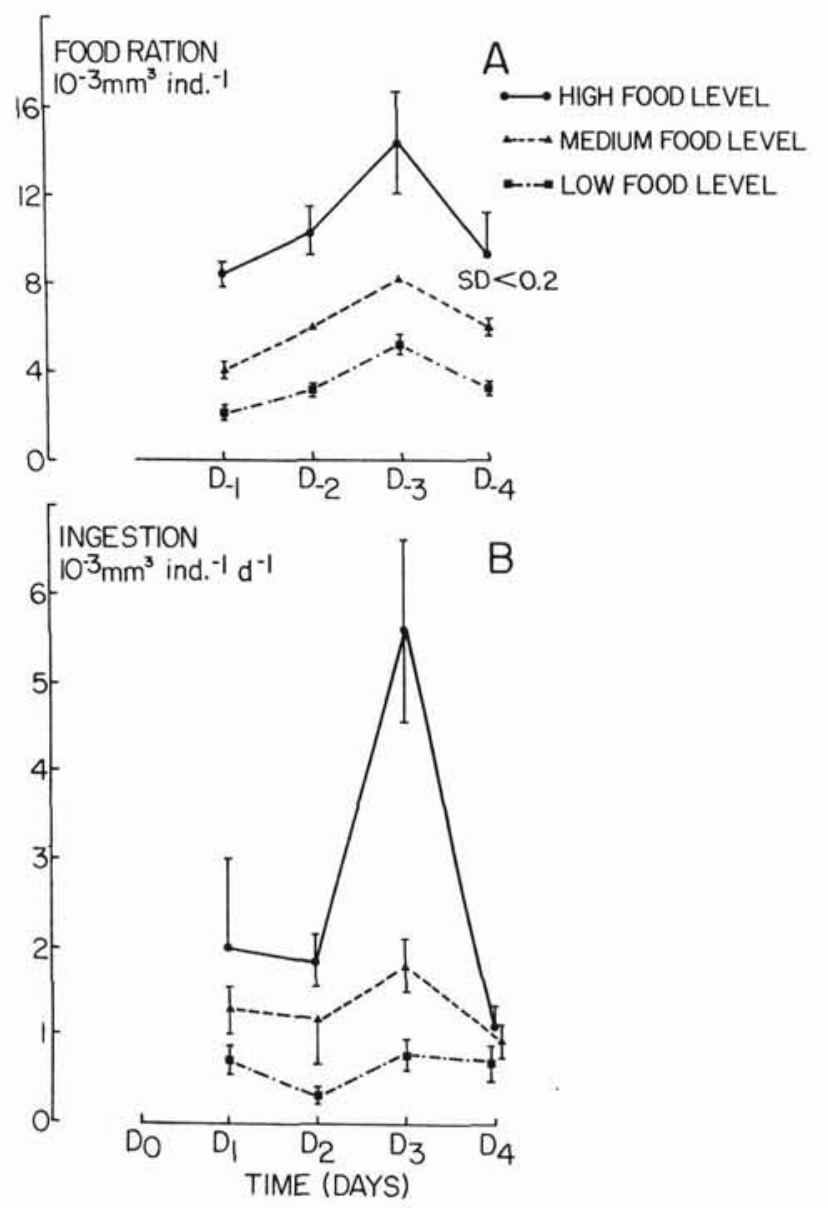

Fig. 2. Acartia clausi. Changes in (A) food ration and (B) ingestion rates for 3 different food levels of the diatom Skeletonema costatum during Expt 1. 'High' food level = initially 14000 cells $\mathrm{ml}^{-1}$ or $2.9 \mathrm{~mm}^{3} \mathrm{1}^{-1}$; 'Medium' food level $=$ initially 7000 cells $\mathrm{ml}^{-1}$ or $1.5 \mathrm{~mm}^{3} \mathrm{l}^{-1}$; 'Low' food level $=$ initially 1500 cells ml $\mathrm{m}^{-1}$ or $0.7 \mathrm{~mm}^{3} \mathrm{l}^{-1}$. Vertical bars indicate standard deviation. $D_{-n}$ stands for the $24 \mathrm{~h}$ delay between food adjustment and ingestion measurement on $D_{n}$

gesting some threshold which compounded the acclimation with the experimental variability.

The changes in amylase, laminarinase and trypsin

Table 2. Skeletonema costatum. Chemical and biochemical composition of different batches of the log-phase culture used in Expt 1. C: carbon; N: nitrogen; Chl: chlorophyll; Prot.: total proteins; T. Carb.: total carbohydrates; S. Carb.: soluble carbohydrates; Lip.: total lipids. Values in parentheses: standard deviation. The negative time scale indicates that the food was added to the experiment vessels $24 \mathrm{~h}$ before the ingestion and enzyme activity measurements

\begin{tabular}{|c|c|c|c|c|c|c|c|c|c|c|c|}
\hline $\begin{array}{l}\text { Sampling } \\
\text { date }\end{array}$ & $\begin{array}{l}\text { Conc. } \\
\left(10^{6}{\left.\text { cells } \mathrm{ml}^{-1}\right)}\right)\end{array}$ & C & $\mathrm{N}$ & $\mathrm{Chl}$ & $\begin{array}{l}\text { Prot. } \\
{ }^{6} \mu \mathrm{g} \mathrm{ce}\end{array}$ & $\begin{array}{l}\text { T. Carb. } \\
{ }^{-1} \text { ) }\end{array}$ & S. Carb. & Lip. & $C: N$ & C:Chl & $\mathrm{N}: \mathrm{Chl}$ \\
\hline Day -1 to -3 & 3.3 & $\begin{array}{c}72 \\
(2)\end{array}$ & $\begin{array}{c}13 \\
(0.1)\end{array}$ & $\begin{array}{c}1.5 \\
(0.5)\end{array}$ & $\begin{array}{l}61 \\
(1)\end{array}$ & $\begin{array}{l}38 \\
(1)\end{array}$ & $\begin{array}{l}38 \\
(2)\end{array}$ & $\begin{array}{c}12 \\
(0.2)\end{array}$ & 5.5 & 48 & 8.7 \\
\hline Day -4 & 5.4 & $\begin{array}{c}85 \\
(0.4)\end{array}$ & $\begin{array}{c}13 \\
(0.1)\end{array}$ & $\begin{array}{c}1.3 \\
(0.5)\end{array}$ & $\begin{array}{l}108 \\
(1)\end{array}$ & $\begin{array}{l}59 \\
(1)\end{array}$ & $\begin{array}{l}37 \\
(5)\end{array}$ & $\begin{array}{c}10 \\
(0.3)\end{array}$ & 6.5 & 65 & 10.0 \\
\hline
\end{tabular}




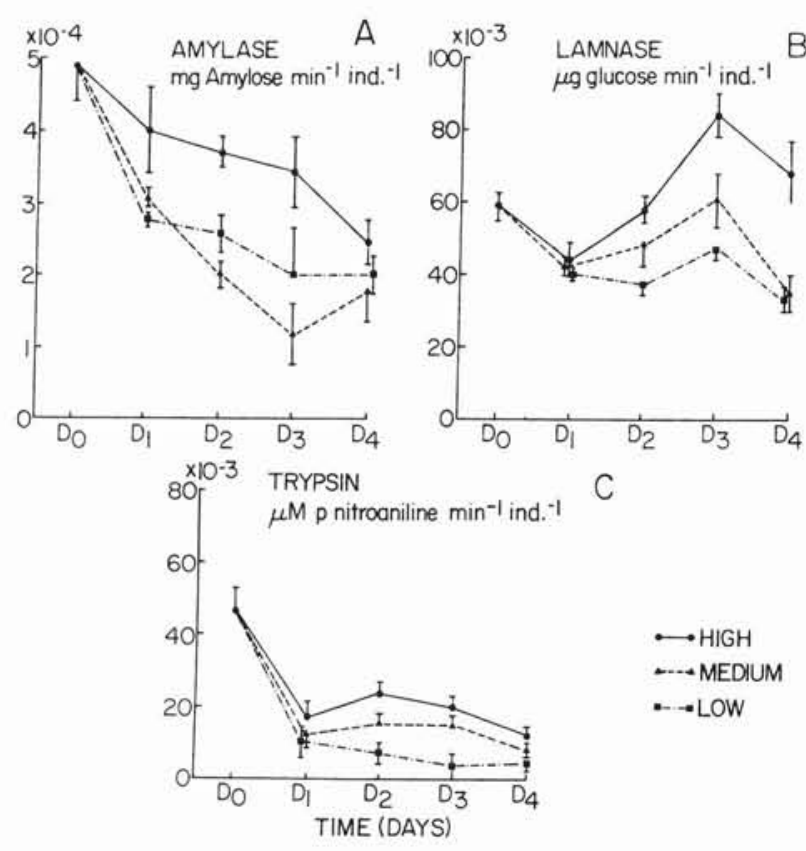

Fig. 3. Acartia clausi. Medium-term acclimation of the digestive enzymes (A) amylase, (B) laminarinase (LAMNASE), and (C) trypsin, subjected to the food changes defined in Expt 1. 'High' = initially 14000 cells $\mathrm{ml}^{-1}$ or $2.9 \mathrm{~mm}^{3} \mathrm{l}^{-1}$; 'Medium' = initially 7000 cells ml $\mathrm{m}^{-1}$ or $1.5 \mathrm{~mm}^{3} \mathrm{l}^{-1}$; 'Low' $=$ initially 1500 cells $\mathrm{ml}^{-1}$ or $0.7 \mathrm{~mm}^{3} \mathrm{1}^{-1}$. Vertical bars indicate standard deviation

activities recorded during the same experiment displayed a sharp decrease during the first day of laboratory confinement followed by a pattern of changes which differed somewhat with the individual enzyme (Fig. 3). Laminarinase and trypsin activities showed respectively complete and partial recovery, while amylase activity diminished throughout the experiment. Those copepods exposed to 'High' food concentration demonstrated a positive acclimation for all enzyme activity after the first $24 \mathrm{~h}$, with significantly higher activities per individual than for those held at 'Medium' and 'Low' levels of food (Wilcoxon 2-samples test; $\mathrm{p}<0.05$ ). The amylase and laminarinase activities recorded for the 2 lower food concentrations were not significantly different (Wilcoxon 2-sample test) whereas trypsin activity was ranked according to the positive acclimation hypothesis, i.e. highest at highest concentration and lowest at the lowest (Wilcoxon 2-sample test; $\mathrm{p}<0.02)$. The influence of the variable day-to-day pattern of ingestion was strongly reflected by laminarinase activity but not evident for the other 2 enzymes.

GDH and ETS activities (Fig. 4) did not vary markedly among the 3 food concentration groups tested. Both activities decreased sharply from the values observed in the field $\left(D_{0}\right)$ and then leveled off at about $20 \%$ more than the activity levels seen in copepods starved for $4 \mathrm{~d}$.
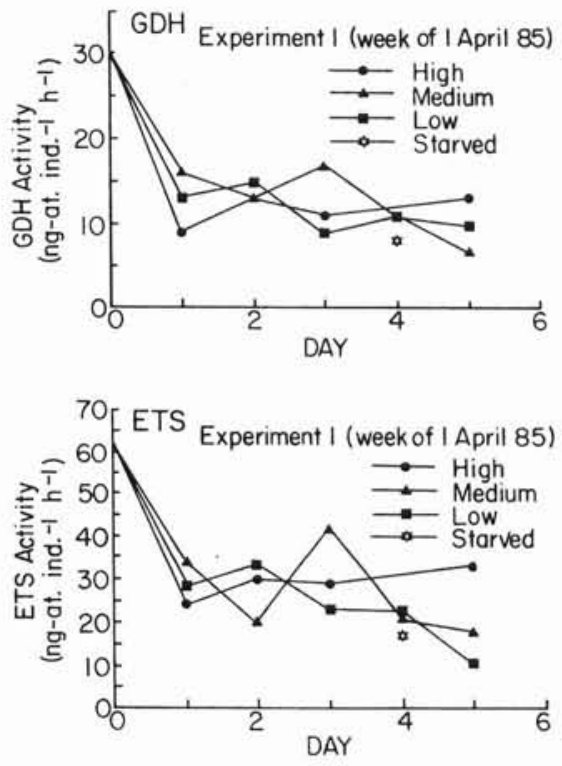

Fig. 4. Acartia clausi. Changes in electron transport system (ETS; ng-at. $\mathrm{O}_{2}$ ind. ${ }^{-1} \mathrm{~h}^{-1}$ ) and glutamate dehydrogenase $\left(\mathrm{GDH}_{i}\right.$ ng-at. $\mathrm{N}$ ind. $\left.{ }^{-1} \mathrm{~h}^{-1}\right)$ specific activities during Expt 1

\section{Expt 2}

The design of the first experiment was essentially concerned with the influence of increasing food supply and left one question unanswered: do the copepods acclimate to medium-term (days) decreasing food concentrations in a way similar to increasing food concentration or is there an influence of the previous trophic history? In Expt 2, after $24 \mathrm{~h}$ acclimation to laboratory conditions in natural seawater, the copepods were introduced to 2 different high food levels of Skeletonema costatum. After $24 \mathrm{~h}$, each of these 2 food concentrations was sharply decreased (by $50 \%$ the first day and by $10 \%$ the remaining 2 d; Fig. 5A). A third group of individuals was maintained without food in filtered seawater as a control.

The characteristics of Skeletonema costatum used in the second experiment are summarized in Table 3. As previously, the cell composition was protein-dominated at all times but both biochemical and chemical compositions showed some variations throughout the experiment. The protein : carbohydrate: lipid ratio varied from $5: 4: 1$ on Days 2 and 3 to $3: 2: 1$ on Day 4 and $10: 6: 1$ on Day 5 when the stock culture had reached stationary phase. Throughout the $5 \mathrm{~d}$ experiment, the diatom's $\mathrm{C}: \mathrm{N}$ ratio remained more or less constant $(5.3 \pm 0.4)$.

A failure of the electronic particle counter halfway through the second experiment prevented us from precisely estimating day-to-day changes in ingestion rate changes. Nevertheless, the few data obtained suggested that ingestion generally tracked the decrease in 
Fig. 5. Acartia clausi. Changes in (A) food ration, and related medium-term acclimation of the digestive enzymes; (B) laminarinase (LAMNASE); (C) amylase and (D) trypsin, for 2 different food levels of the diatom Skeletonema costatum during Expt 2. 'High' = initially 70000 cells $\mathrm{ml}^{-1}$ or $19 \mathrm{~mm}^{3} \mathrm{l}^{-1}$; 'Low' = initially 14000 cells ml $\mathrm{m}^{-1}$ or $3.5 \mathrm{~mm}^{3} \mathrm{l}^{-1}$; 'Starved' = starved control copepods. Vertical bars indicate standard deviation
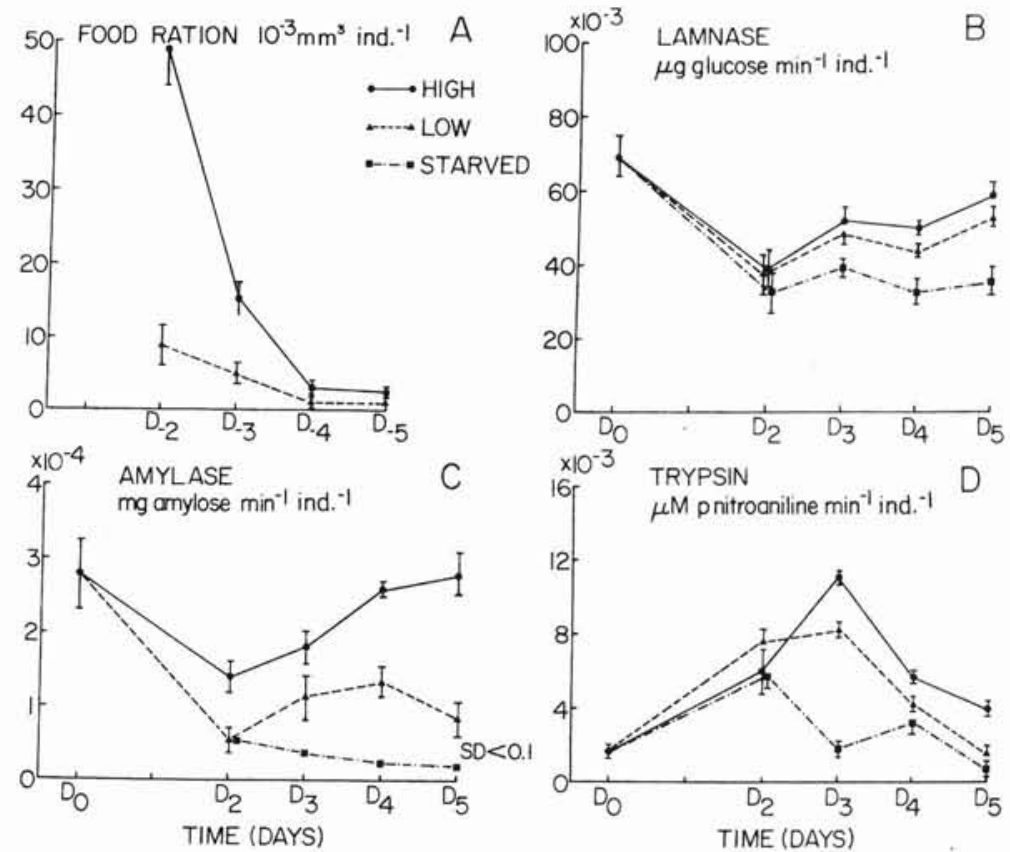

Table 3. Skeletonema costatum. Chemical and biochemical composition of different batches of the log-phase culture used in Expt 2. (For key to symbols, see Table 2)

\begin{tabular}{|c|c|c|c|c|c|c|c|c|c|c|c|}
\hline $\begin{array}{l}\text { Sampling } \\
\text { date }\end{array}$ & $\begin{array}{c}\text { Conc. } \\
\left(10^{6} \text { cells } \mathrm{ml}^{-1}\right)\end{array}$ & C & $\mathrm{N}$ & $\begin{array}{l}\text { Chl } \\
\text { (1 }\end{array}$ & $\begin{array}{l}\text { Prot. } \\
{ }^{6} \mu \mathrm{g} \mathrm{ce}\end{array}$ & $\begin{array}{l}\text { T. Carb. } \\
\left(^{-1}\right)\end{array}$ & S. Carb. & Lip. & C:N & $\mathrm{C}: \mathrm{Chl}$ & $\mathrm{N}: \mathrm{Chl}$ \\
\hline Day $-2-3$ & 2.3 & $\begin{array}{l}75 \\
(1)\end{array}$ & $\begin{array}{c}13 \\
(0.1)\end{array}$ & $\begin{array}{c}1.1 \\
(0.1)\end{array}$ & $\begin{array}{l}54 \\
(1)\end{array}$ & $\begin{array}{l}45 \\
(2)\end{array}$ & $\begin{array}{l}43 \\
(3)\end{array}$ & $\begin{array}{c}11 \\
(1.5)\end{array}$ & 5.8 & 68 & 12 \\
\hline Day -4 & 1.0 & $\begin{array}{l}74 \\
(5)\end{array}$ & $\begin{array}{c}15 \\
(0.2)\end{array}$ & $\begin{array}{c}0.8 \\
(0.1)\end{array}$ & $\begin{array}{l}55 \\
(1)\end{array}$ & $\begin{array}{c}42 \\
(0.5)\end{array}$ & $\begin{array}{l}37 \\
(2)\end{array}$ & $\begin{array}{c}21 \\
(1)\end{array}$ & 4.9 & 93 & 19 \\
\hline Day -5 & 5.4 & $\begin{array}{c}85 \\
(0.4)\end{array}$ & $\begin{array}{c}15 \\
(0.1)\end{array}$ & $\begin{array}{l}1.0 \\
(0.1)\end{array}$ & $\begin{array}{l}98 \\
(5)\end{array}$ & $\begin{array}{c}59 \\
(1)\end{array}$ & $\begin{array}{l}37 \\
(5)\end{array}$ & $\begin{array}{c}10 \\
(0.3)\end{array}$ & 5.7 & 85 & 13 \\
\hline
\end{tabular}

the available food supply. In contrast to the previous experiment where field-collected copepods had high activities of all 3 enzymes, all the copepods captured on 13 May displayed very low trypsin activity coupled with relatively high amylase and laminarinase activities (compare $\mathrm{D}_{0}$ conditions Fig. $5 \mathrm{~B}$ to D). Exposure to different levels of food supply for a short time $(24 \mathrm{~h})$ did not seem to influence the enzyme levels $\left(D_{2}\right)$ which, except for amylase, remained similar to the activity exhibited by the starved control individuals. However, positive acclimation became evident during the next $3 \mathrm{~d}$, even though the food available was drastically decreasing (Fig. 5A), suggesting a strong memory effect. A Wilcoxon 2-sample test confirmed that the enzyme responses were significantly different $(\mathrm{p}<0.05)$ and could again be ranked according to the food supply ( $D_{2}$ for trypsin excepted). Over time, amylase and laminarinase of fed copepods displayed significant variations (Kruskal-Wallis test; $0.01<\mathrm{p}<0.05$ ) with an initial decrease over the first $2 \mathrm{~d}$, followed by either a stabilization or slow increase in activity (Fig. 5B, C). Trypsin also showed significant variations (Kruskal-Wallis test; $\mathrm{p}<0.01$ ) with a maximum activity occurring $24 \mathrm{~h}$ after the initial pulse of food supply, followed by a decrease which agreed with that of the food concentrations. Thus, the data suggest that the reactivity of the enzyme system varies with the enzyme considered and that under the present experimental conditions trypsin activity is the only one to both show an acclimation to food concentration and reflect the decreasing characteristic of the food availability.

Once again, the changes in ETS and GDH activities 

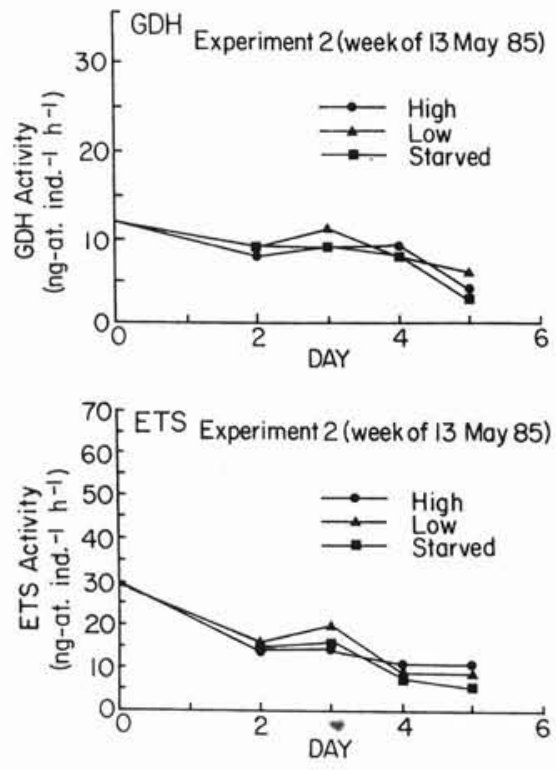

Fig. 6. Acartia clausi. Changes in electron transport system (ETS) and glutamate dehydrogenase (GDH) specific activities for the 2 food levels and starving individuals defined in Expt 2. 'High' $=70000$ cells ml ${ }^{-1}$ or $19 \mathrm{~mm}^{3} \mathrm{l}^{-1}$; 'Low' $=14000$ cells $\mathrm{ml}^{-1}$ or $3.5 \mathrm{~mm}^{3} \mathrm{l}^{-1}$; 'Starved' $=$ starved control copepods

failed to show a positive functional response to either of the 2 food levels. Fig. 6 demonstrates that the activities of individuals exposed to both food regimes decreased with time, ultimately reaching ETS and GDH levels similar to those exhibited by starving late-winter collected specimens.

\section{Expt 3}

The time-averaging phenomenon which seemed to characterize the enzyme response in the previous 2 experiments cannot be fully identified using a single short pulse type experiment. Consequently, for the third experiment the copepods were acclimated for $24 \mathrm{~h}$ in natural seawater to laboratory conditions and then sub-
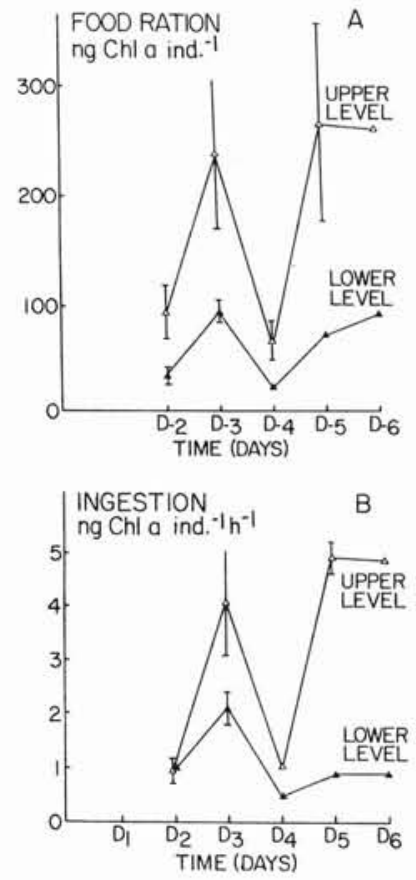

Fig. 7. Acartia clausi. Medium-term changes in (A) food ration, and (B) ingestion rates, for 2 different food levels of the diatom Skeletonema costatum during Expt 3. Initial concentrations were similar to those of Expt 2 (see Fig. 5). Vertical bars indicate standard deviation. For time axis legend see Fig. 1

jected to 2 successive pulses of Skeletonema costatum over $4 \mathrm{~d}$ (Fig. 7, top). The 2 food levels used were identical to those used in Expt 2 and as previously a group of nonfed copepods was used as control. The diatom cells, which were harvested during the stationary growth phase, except on Day 2, contained a considerably higher concentration of carbohydrates than cells from Expt 2. Soluble polysaccharides made up 76 to $96 \%$ of the total carbohydrates, while the protein:carbohydrate:lipid ratio displayed some important variations with values of $4: 7: 1$ on Days 2, 5 and 6, 9:8:1 on Day 3 and $6: 7: 1$ on Day 4 (Table 4). However, the $\mathrm{C}: \mathrm{N}$ ratio showed less variation, with most values ranging between 7.1 and 8.1.

Table 4. Skeletonema costatum. Chemical and biochemical composition of different batches of the stationary phase culture used in Expt 3. (For key to symbols, see Table 2)

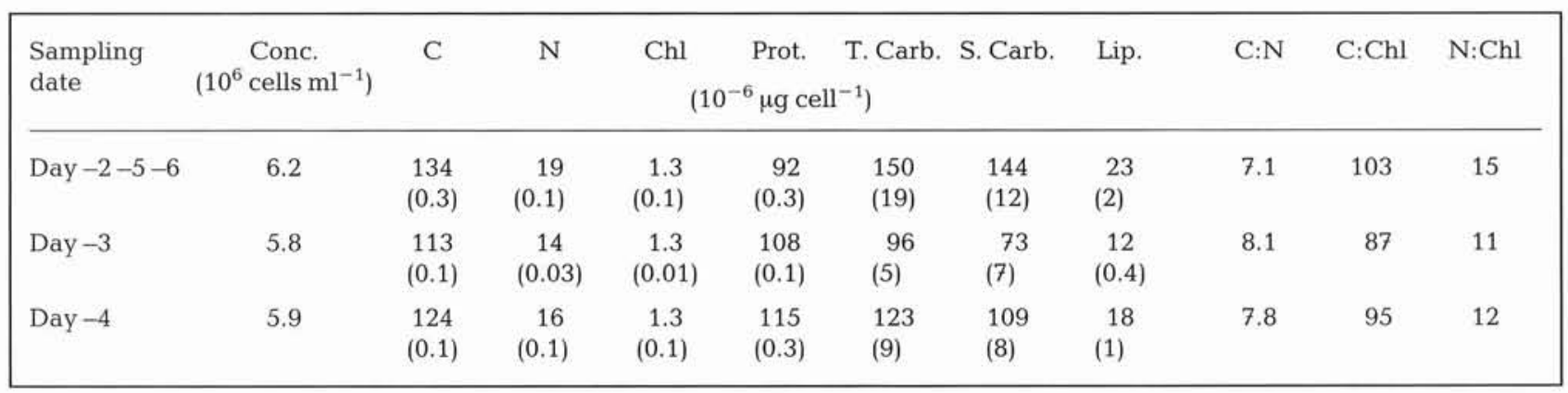




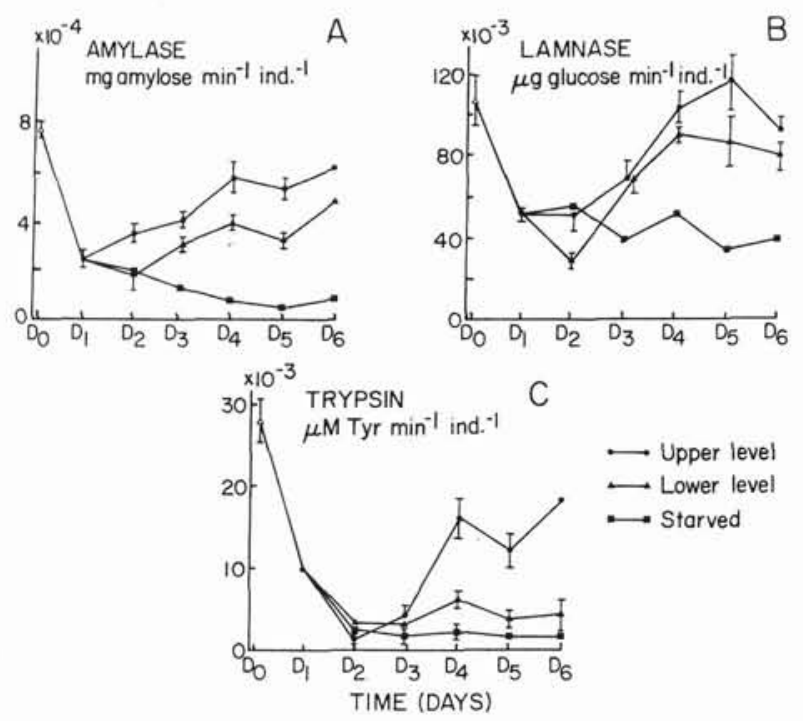

Fig. 8. Acartia clausi. Medium-term acclimation of the digestive enzymes (A) amylase, (B) laminarinase (LAMNASE), and (C) trypsin, for the 2 different food levels of the diatom Skeletonema costatum during Expt 3. Initial concentrations were similar to those of Expt 2 (see Fig. 5). Vertical bars indicate standard deviation; 'starved' $=$ starved control copepods

The general pattern of changes in ingestion rate closely followed the oscillatory nature of the food availability, with differences in ingestion at the upper and lower level most pronounced when differences in food ration were most marked (Days 3, 5 and 6; Fig. 7). The significance of the general trend was tested using the non-parametric Kruskal-Wallis test $(p<0.03)$, while that of the acclimation to food level was verified by a Wilcoxon 2 -sample test $(\mathrm{p}<0.02)$.

As was the case in the previous experiments, all 3 digestive enzyme activities (i.e. amylase, laminarinase, trypsin) showed a marked initial decrease related to the laboratory acclimation $\left(D_{1}\right)$ which was not fully reversed after the first $24 \mathrm{~h}$ of feeding $\left(\mathrm{D}_{2}\right)$ (Fig. 8A to C). Significant positive acclimation to the food concentration had set in by Day 3 (Wilcoxon 2-sample test; $\mathrm{p}<0.01$ ), even though oscillations in ingestion rates seem attenuated in terms of enzyme changes and shifted rhythmicity was apparent for trypsin activity. The amylase and laminarinase activities at high food concentration demonstrated almost complete recovery to their initial 20 May field levels, which might reflect the dominance of carbohydrates in the diet. The same significant trend (KruskalWallis test; $\mathrm{p}<0.02$ ) was apparent for the low food level carbohydrase activities, although good discrimination between feeding and non-feeding groups was only established after the second day (Fig. 8). Recovery of trypsin activity was more limited and observed only for the higher food concentration. The general variation in trypsin activity at lower food level was more attenu-
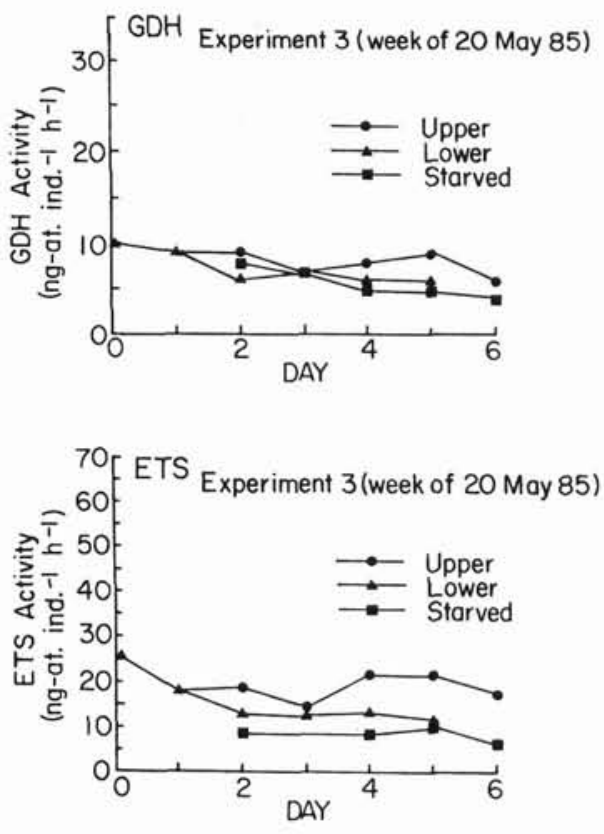

Fig. 9. Acartia clausi. Changes in the electron transport system (ETS) and glutamate dehydrogenase (GDH) specific activities for the 2 food levels and starving individuals during Expt 3. 'Starved' = starved control copepods; initial food levels similar to those of Expt 2 (see Fig. 5)

ated, although it tested significant (Kruskal-Wallis test, $\mathrm{p}<0.05$ ) when compared to the uniformly low trypsin activity of starved control specimens.

The time course of variation in GDH and ETS activities showed some differences between upper and lower/starved conditions, although neither exhibited a clear relationship with the variation in food supply (Fig. 9). As already described for the digestive enzymes, the overall trend corresponded to an initial decrease in activity, but this was followed by an almost complete recovery of GDH and ETS activity at the upper food levels to oscillate about mean activity some $50 \%$ higher than that of unfed copepods.

\section{Expt 4}

From a theoretical point of view, positive acclimation of the digestive system should be related to previous or actual food limitation. Once fully acclimated in the laboratory under non-limiting conditions (1 to $2 \mathrm{mgC}$ $1^{-1}$ ), current theory predicts that further pulses in food supply should not result in large changes in digestive enzyme activity. Consequently, for our final experiment, the copepods were acclimated for $5 \mathrm{~d}$ under laboratory conditions with Skeletonema costatum as food source, then subjected to a pulse of the larger Hymenomonas elongata for $3 \mathrm{~d}$ before being returned to the original diet of $S$. costatum for another $3 \mathrm{~d}$. 
Table 5. Skeletonema costatum and Hymenomonas elongata. Chemical and biochemical composition of different batches of the stationary phase cultures used in Expt 4. (For key to symbols, see Table 2)

\begin{tabular}{|c|c|c|c|c|c|c|c|c|c|c|c|}
\hline $\begin{array}{l}\text { Sampling } \\
\text { date }\end{array}$ & $\begin{array}{c}\text { Conc. } \\
\left(10^{6} \text { cells } \mathrm{ml}^{-1}\right)\end{array}$ & C & $\mathrm{N}$ & Chl & $\begin{array}{l}\text { Prot. } \\
{ }^{6} \mu \mathrm{g} \mathrm{ce}\end{array}$ & $\begin{array}{l}\text { T. Carb. } \\
-1 \text { ) }\end{array}$ & S. Carb. & Lip. & $\mathrm{C}: \mathrm{N}$ & $\mathrm{C}: \mathrm{Chl}$ & $\mathrm{N}: \mathrm{Chl}$ \\
\hline $\begin{array}{l}\text { S. costatum } \\
\text { (all samples) }\end{array}$ & 6.20 & $\begin{array}{l}144 \\
(3)\end{array}$ & $\begin{array}{l}20 \\
(1)\end{array}$ & $\begin{array}{r}1.5 \\
(0.1)\end{array}$ & $\begin{array}{l}102 \\
(3)\end{array}$ & $\begin{array}{r}160 \\
(19)\end{array}$ & $\begin{array}{l}153 \\
(12)\end{array}$ & $\begin{array}{l}23 \\
(2)\end{array}$ & 7.2 & 96 & 13 \\
\hline $\begin{array}{l}\text { H. elongata } \\
\text { Day }-6-7\end{array}$ & 1.10 & $\begin{array}{l}1860 \\
(200)\end{array}$ & $\begin{array}{l}200 \\
(16)\end{array}$ & $\begin{array}{l}31.7 \\
(0.4)\end{array}$ & $\begin{array}{l}991 \\
(51)\end{array}$ & $\begin{array}{c}2150 \\
(40)\end{array}$ & $\begin{array}{l}1610 \\
(3)\end{array}$ & $\begin{array}{l}430 \\
(61)\end{array}$ & 9.3 & 59 & 6.3 \\
\hline Day -8 & 1.23 & $\begin{array}{l}2090 \\
(40)\end{array}$ & $\begin{array}{l}170 \\
(1)\end{array}$ & $\begin{array}{l}28.0 \\
(0.3)\end{array}$ & $\begin{array}{l}972 \\
(15)\end{array}$ & $\begin{array}{l}2090 \\
(14)\end{array}$ & $\begin{array}{l}1430 \\
(4)\end{array}$ & $\begin{array}{l}430 \\
(22)\end{array}$ & 12.3 & 75 & 6.1 \\
\hline
\end{tabular}

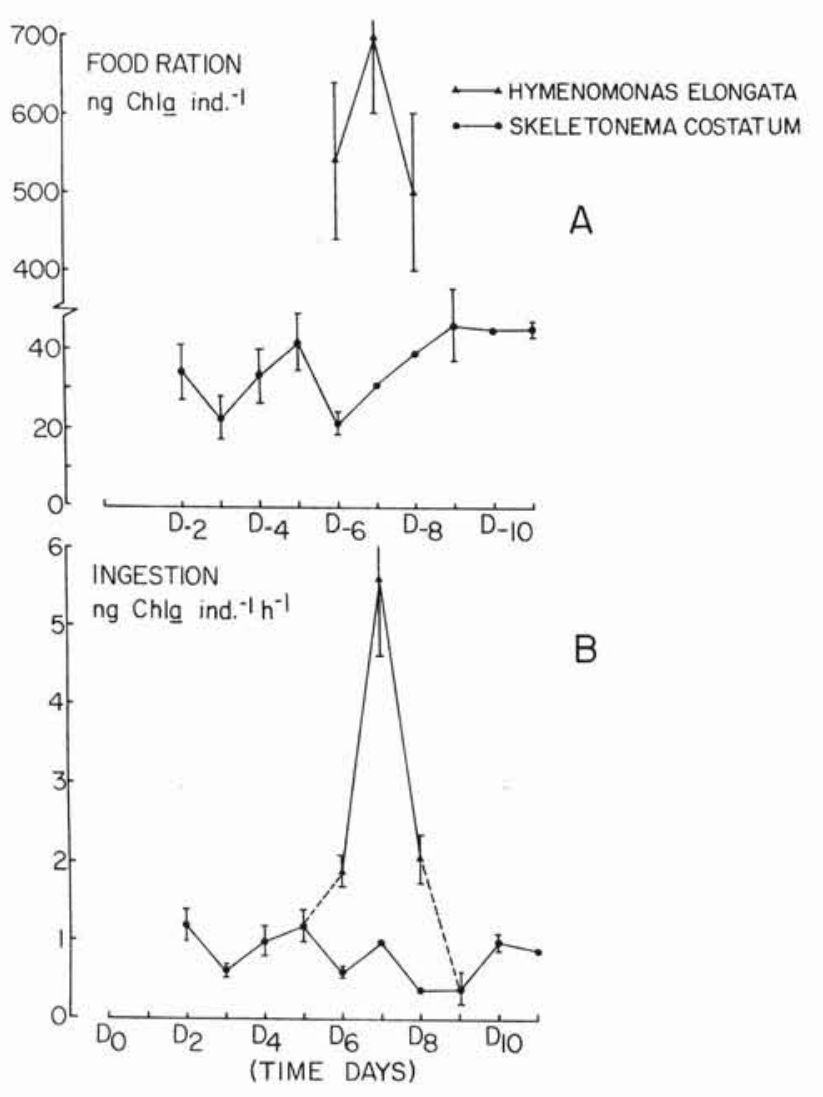

Fig. 10. Acartia clausi. Long-term changes (10 d) in (A) food ration and (B) ingestion rates for 1 food level (10 to $16 \mu \mathrm{g}$ chl $1^{-1}$ ) of the diatom Skeletonema costatum and for a short saturating pulse ( $3 \mathrm{~d})$ of the chrysophycae Hymenomonas elongata during Expt 4. Vertical bars indicate standard deviation

The food level and culture of Skeletonema costatum used were similar to the low concentration of the previous experiment. The diatom culture was again harvested during the stationary phase and was carbohydrate-dominated (Table 5). We introduced the chrysophyte Hymenomonas elongata because laboratory rearing studies (Yassen 1985) have demonstrated that it is a 'good' maintenance food source for the culture of Acartia-type copepods. The $H$. elongata culture used was also harvested during the early sationary phase and displayed similar biochemical characteristics. The protein: carbohydrate: lipid ratio varied between $4: 7: 1$ for $S$. costatum and 2:5:1 for $H$. elongata. Values for the $\mathrm{C}: \mathrm{N}$ ratio of both cultures varied between 7.2 and 12.3, while their soluble polysaccharide contents ranged from 68 to $96 \%$ of the total carbohydrates.

As expected, the ingestion rate tracked the available food ration, although the amount of Hymenomonas elongata actually ingested was not strictly proportional to the 20 -fold increase in available chlorophyll that we added in this $3 \mathrm{~d}$ pulse (Fig. 10).

The digestive enzyme activities oscillated about mean activity which did not strikingly increase when the pulse of Hymenomonas elongata was introduced (Fig. 11). In fact, the controls fed on Skeletonema costatum generally had equivalent or higher digestive enzyme activities than the copepods fed on $\mathrm{H}$. elongata. The specific patterns of changes observed fell into 2 categories: (1) an overall decrease in activity followed by a partial recovery to between 50 and $75 \%$ of the initial activity (e.g. amylase), or (2) an initial decrease followed by a more or less complete recovery back to the initial field activity (e.g. the other 3 enzymes). As expected, laminarinase, trypsin and alkaline protease activities were significantly intercorrelated $(0.05<\mathrm{p}$ $<0.01$ ) with maximum activities either during or $2 \mathrm{~d}$ after the pulse of $H$. elongata (Fig. 11). As we will see later, this increase apparently reflected a general increase in intermediate metabolism.

ETS and GDH activity covaried for the first $5 \mathrm{~d}$ of the experiment but diverged after Hymenomonas elongata was presented (Fig. 12). The ETS activity clearly increased in response to $H$. elongata as food supply to reach activity levels comparable to those in the field at the time and twice those of the corresponding controls fed on Skeletonema costatum. A correlation analysis confirmed the similarities among changes of ETS, laminarinase and proteases $(0.05<\mathrm{p}<0.01 ; \mathrm{r}>0.64, \mathrm{df}=9)$. 
Fig. 11. Acartia clausi. Long-term acclimation of the digestive enzymes (A) amylase, (B) laminarinase (LAMNASE), (C) trypsin, and (D) alkaline proteases activities to change in the limiting food supply of the diatom Skeletonema costatum and short-term acclimation to a saturating pulse of the chrysophysae Hymenomonas elongata during Expt 4. Vertical bars indicate standard deviation
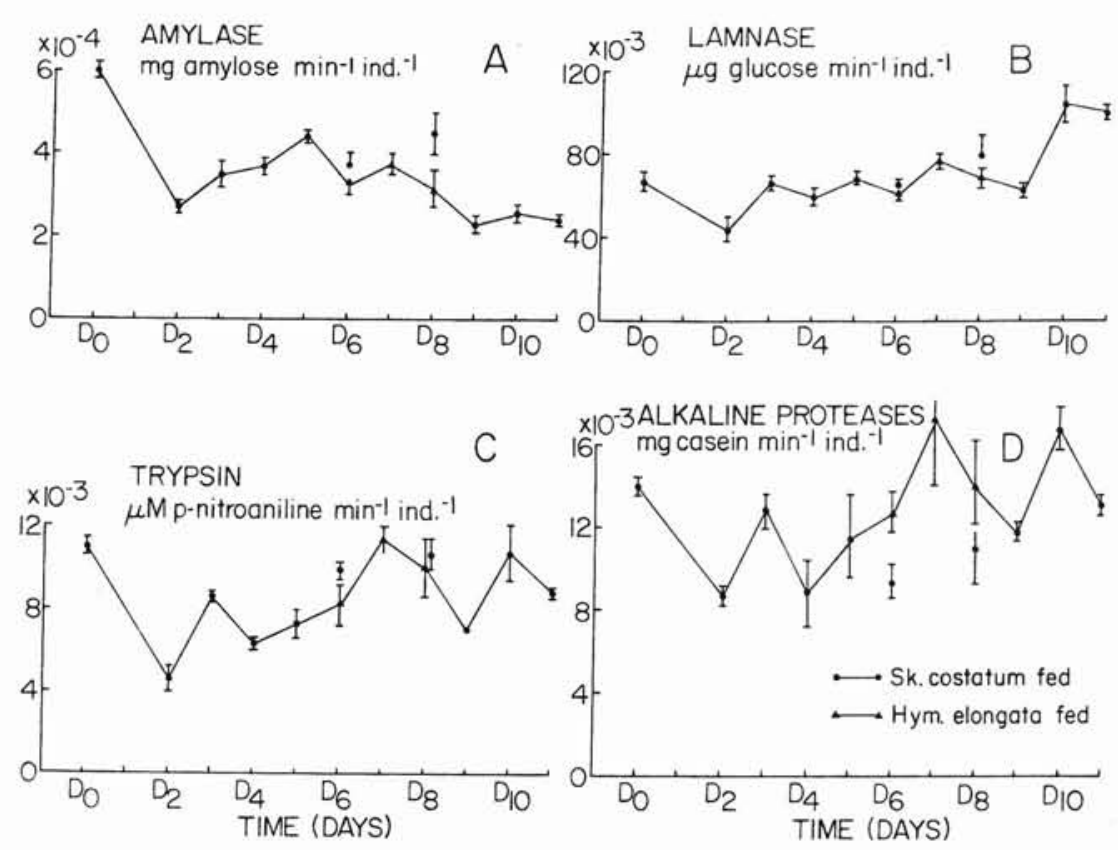

\section{DISCUSSION}

The acclimation hypothesis, first proposed by Mayzaud \& Poulet (1978) and completed by Mayzaud \& Mayzaud (1985) and Mayzaud (1986), suggested that small neritic copepods under food-limiting conditions acclimated behaviourly and biochemically to time-averaged food concentrations. Experimental demonstration of digestive acclimation has been limited to a small number of studies with contradictory conclusions. Cox (1981) and Cox \& Willasson (1981) demonstrated a specific positive acclimation of laminarinase in Euphausia pacifica and Calanus pacificus feeding on the diatom Skeletonema costatum or particulate laminarin and found a time course of $1 \mathrm{~d}$. Head \& Conover (1983) also described a positive response of amylase, laminarin-

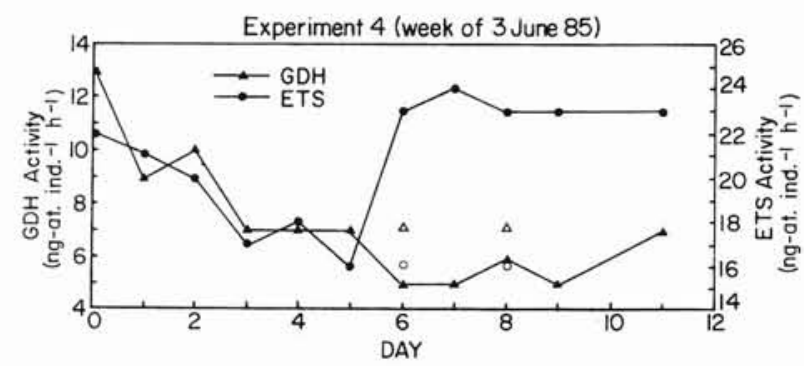

Fig. 12. Acartia clausi. Changes in electron transport system (ETS) and glutamate dehydrogenase (GDH) specific activities for individuals fed limiting levels of the diatom Skeletonema costatum and subjected to a pulse of saturating concentrations of the chrysophysae Hymenomonas elongata on Days 6 to 8 . Open symbols: controls fed on $S$. costatum during the pulse of H. elongata ase and protease activities in Calanus hyperboreus fed different phytoplankters but observed a temperaturedependent time course of 8 to $16 \mathrm{~d}$. More than likely, the use of late diapausing copepods which did not feed until 5 din the laboratory explains both the long time scale and the non-specificity observed. As we will see later, a time course of 24 to $48 \mathrm{~h}$ for medium-term digestive acclimation seems more representative of actively feeding copepods. Other studies by Hassett \& Landry (1983, 1988) on C. pacificus and Harris et al. (1986) on Calanus helgolandicus led to negative relationships between potential food supply and digestive enzyme activity but these authors reached somewhat differing conclusions. Hassett \& Landry (1983) suggested that the maintenance of high levels of digestive enzymes could be in anticipation of future feeding opportunity, while Harris et al. (1986) proposed that such results indicated a compensatory mechanism to maintain assimilation rate under nonlimiting food situations.

The contradictions between these different studies and our results should be analyzed both from a methodological and theoretical point of view. As indicated by Mayzaud (1986), changes in digestive enzyme activities are likely to be representative of the ability to adapt to variations in food supply in order to achieve through assimilation the best possible fulfilment of metabolic requirements. Such dual control by the food concentration and the metabolic needs imposes on any experimental design: (1) a choice of enzyme representative of the digestive processes, (2) a continued existence of a food-limiting environment (i.e. suboptimal growth conditions), and (3) the persistence of similar metabolic requirements. 
Considering the key role of protein nutrition (Paffenhöfer \& Van Sant 1985, Libourel-Houde \& Roman 1987, Hassett \& Landry 1988, Cowles et al. 1988), a balanced description of digestive system activity should monitor proteases as well as those glycosidases involved in the extracellular digestion. In our opinion, the choice by Hassett \& Landry $(1983,1988)$ to focus exclusively on glycosidases was unfortunate, for it left unknown the possibility of a differential response in the proteolytic activities like that documented in the present study, and more recently for an Antarctic, lipidrich copepod (Drepanopus pectinatus; Mayzaud et al. unpubl.). Moreover, Hassett \& Landry's selection of maltase and cellobiase as concurrent test enzymes was problematical as both are involved in the intracellular phase of digestion and are not likely to be directly related to food intake.

Proper characterization of the experimental food conditions has been an important problem in most studies for it should be related to the nutritional status of the animals. Harris et al. (1986) used different food items at concentrations varying between 969 and 2149 $\mu \mathrm{gC} 1^{-1}$; such concentrations represented a non-limiting trophic environment as attested by the stability of the body protein level throughout the experiment, irrespective of the food source or concentration. In contrast, although Hassett \& Landry (1983) used food concentrations ranging from 200 to $1452 \mu \mathrm{gC} \mathrm{l}^{-1}$, the recorded changes in dry weight suggested that maximum copepod growth (non-limitation) was achieved only at their 2 highest experimental food concentrations $\left(4200\right.$ cells $\mathrm{ml}^{-1}=924 \mu \mathrm{gC}^{-1}$ and 660 cells $\mathrm{ml}^{-1}=1452 \mu \mathrm{gC}^{-1}$ ) while limitation seemed to occur at the first 2 concentrations $\left(1000\right.$ cells ml $\mathrm{ml}^{-1}=220 \mu \mathrm{gC}$ $\mathrm{1}^{-1}$ and 2000 cells $\mathrm{ml}^{-1}=440 \mu \mathrm{gC}^{-1}$ ) although to a lesser degree than in the natural environment. In the present experiments, even though Skeletonema costatum concentrations were increased an order of magnitude, from 360 to $5600 \mu \mathrm{gC} 1^{-1}$ (1.5 to $18 \mu \mathrm{gC}$ per Acartia clausi) during the course of our laboratory evaluation, this range of food ration appeared to be generally limiting.

Unchanging levels of metabolic requirements are extremely difficult to achieve as they would require laboratory conditions which perfectly simulate the natural ones. Nevertheless, probable changes should be kept in mind during the interpretation of acclimation experiments. As indicated by Donaghay (1988), changes in growth response or egg production are not only related to food availability but also to previous history or preconditioning of the animals. Intuitively, one would expect that switching an organism from a turbulent, patchy food environment to laboratory conditions would result in changes in the energy and metabolic requirements associated with the new life environment.
From these considerations and the arguments developed by Samain et al. (1981) for Artemia and by Mayzaud \& Mayzaud (1985) for neritic copepods, we suggest that the apparent contradictions between various laboratory experiments can be reconciled by considering the experimental trophic situations. Harris et al. (1986) designed their experiments to achieve saturating conditions, where maximal growth and/or egg production could be achieved. Under such conditions, the copepods they used had no need to acclimate, as any increase in food supply was surfeit and digestive enzyme levels varied according to a compensatory mechanism between the digestive enzyme activity and the substrate ingested, i.e. the copepods adjusted their digestion and assimilation rates to their metabolic needs. Hassett \& Landry (1983), on the other hand, experimented with both non-saturating conditions and saturating conditions, and tracked what, in our opinion, were enzymes not expected to be fully coupled to extracellular digestive processes. Indeed, endocellular enzymes hydrolyze those molecules resulting from the action of the extracellular digestion and are not directly related to the molecules ingested. The higher enzyme activity they reported for the 2 lower, food-limiting regimes would have been expected from the experimental conditions they imposed as positive acclimation only occurred for these 2 food concentrations. In summary both of these studies illustrated very specific trophic situations which were not central to the Mayzaud \& Poulet (1978) acclimation hypothesis.

The results we obtained in the first 3 experiments of the present study clearly confirm that Acartia-type copepods exposed to different food-limiting levels will positively adjust both their feeding pattern and their digestive enzyme activities, although these adjustments do not necessarily occur on identical time scales. For example, while changes in ingestion closely tracked day-to-day variations in food supply, changes in digestive enzyme activities were functionally linked to the medium-term, time-averaged food concentration and the medium-term, time-averaged ingestion.

In all our experiments, in situ enzyme activities $\left(D_{0}\right)$ could be not be maintained under laboratory conditions and a transition period of 1 to $3 \mathrm{~d}$ was manifest before the new 'food regime(s)' could be correlated significantly with digestive enzymes. Note that this 1 to $3 \mathrm{~d}$ transition was necessary, irrespective of whether the copepods were previously acclimated (Expts 2 and 3) or not (Expt 1) to our laboratory environment. Starvation consistently resulted in a decrease of activity but, as already observed by Boucher \& Samain (1974) and by Mayzaud \& Mayzaud (1985), such a decrease in digestive enzyme activity generally had a lag time of 1 to $2 \mathrm{~d}$.

The lack of significant differences between amylase (or laminarinase) activities between low and medium 
food levels (350 and $700 \mu \mathrm{gC}^{-1}$ ) in Expt 1 was surprising especially when compared to the reactivity of the trypsin system. Such differences among enzyme systems suggest there may be a differential threshold of sensitivity which may functionally enhance the potential for protein assimilation at low food concentration. We suggest that such data underline the importance of protein assimilation for meeting the metabolic requirements of copepods, as already emphasized by Paffenhöfer \& Van Sant (1985), Libourel-Houde \& Roman (1987), Hassett \& Landry (1988) and Cowles et al. (1988). In Expt 2, decreasing the food ration failed to initiate parallel decrease of any glycosidase activities but it strongly induced a drop in trypsin activity with a $24 \mathrm{~h}$ delay. Interestingly, the lack of a sharp decrease in glycosidase activities was still associated with a positive acclimation to the time-averaged food concentration, suggesting the existence of 2 different levels of time regulation processes that are diversely affected by the 'memory effect' from the initial food conditions. The acclimation to the difference in food levels was unaffected by the direction of the food concentration changes which was only reflected by those enzyme with low initial activity level, i.e. small 'memory effect'. We believe it probable that the initial high food level $\left(D_{2}\right)$ increased the duration of the memory effect associated with already high natural glycosidase activities. In Expt 3, successive pulses of phytoplankton were not recorded by either amylase or laminarinase but induced a $24 \mathrm{~h}$ shifted rhythmicity of trypsin at high food level. The dominance of carbohydrates over proteins in the food ration may explain the more limited induction of trypsin at the lower food concentration.

In Expt 4, longer-term acclimation at medium and more or less constant food ration ( 3 to $4 \mu \mathrm{gC}$ ind. ${ }^{-1}$ ) showed that over an $8 \mathrm{~d}$ period, the day-to-day fluctuation in ingestion rates had no marked influence on the corresponding enzyme activity. Thus, variation in excess of 1 and $2 \mu \mathrm{gC}$ ind. ${ }^{-1}$ is probably required for the digestive enzyme system activity to fluctuate in response. It is worth noting that introducing a pulse of saturating food ration resulted in a stabilization (or a small decrease) in 3 of the 4 enzyme activities monitored. The limited increase in alkaline protease activity, when compared with the sharp increase in ingestion rate from Days 6 to 8, probably reflects a general increase in intermediary metabolism, evident from the ETS data. In summary, our final feeding experiment confirmed that medium-term acclimation of digestive enzyme activity is best demonstrated and is likely restricted to situations of food limitation.

In an earlier study, Mayzaud \& Poulet (1978) suggested that between $24 \mathrm{~h}$ and 6 days was required for the enzyme system to acclimate, but could not define the minimum size of the food ration which might ini- tiate such adaptation. Under the present experimental conditions, Acartia clausi appeared to require $48 \mathrm{~h}$ to demonstrate a significant acclimation with changes in food ration exceeding a threshold of 1.5 to $2 \mu \mathrm{gC}$ ind.$^{-1}$. Positive responses were recorded over a range of 2 to $12 \mu \mathrm{gC}$ ind $^{-1}$ but were more sustained for discontinuous food stimuli. These results agree with the early findings by Cox (1981) and Cox \& Willasson (1981) and explain the lack of short-term experimental changes (4 to $6 \mathrm{~h}$ ) described by Hassett \& Landry (1988). However, they do not support the various field reports of diel changes in enzyme activity (Boucher \& Samain 1974, Tande \& Slagstad 1982, Båmstedt 1984, 1988, Mayzaud et al. 1984).

The validity of a direct comparison between shortterm and medium-term acclimation must be considered carefully. We might anticipate that short-term changes in digestive processes would be associated with the cycles of active feeding ( 6 to $8 \mathrm{~h}$ ) and controlled by the sequence of gut processes. Most of the digestion takes place in the midgut, and 4 main cell-types are usually associated with that sequence: (1) R-cells (equivalent to the absorptive cells of decapods), (2) F-cells (site of synthesis of the digestive enzymes involved in extracellular digestion), (3) E-cells (undifferentiated which can develop into either R or F cells, and (4) Bcells (responsible for intracellular digestion) which must disintegrate to release their digestive products before assimilation by the R-cells (Arnaud et al. 1978, 1980, 1983, 1984a, b). In a recent study, Nott et al. (1985) showed that at the onset of feeding, Calanus helgolandicus F-cells were still in their developmental stage while B-cells were small, reduced in number and showed little sign of bursting into the gut lumen. In contrast, $1 \mathrm{~h}$ after feeding some B-cells had disintegrated and this process was almost complete at the end of $7 \mathrm{~h}$. Since B-cells cannot be replaced continuously, a rebuilding period is required to reset the digestive structure.

Detailed data on the cycle of F-cells are lacking for copepods but the time courses of the processes are probably analogous to those that occur in decapod crustacea (Mohanna-Al et al. 1985): (1) for about 30 min after feeding F-cells contain numerous zymogen-like granules; (2) these granules decrease in frequency after 1 or $2 \mathrm{~h}_{\text {; }}$ (3) when the more proximal Fcells have released most of their enzyme content, they differentiate into early stage B-cells. If similar processes occur in most copepods, individuals fed at saturation level will see their enzyme production limited by the availability of F-cells and B-cells, while individuals feeding at lower concentrations will be able to extend their feeding and digestive period. Note that in both cases, the copepods themselves have no possibility for short-term modification of their digestive capabilities, 
except through allosteric changes in the rate of enzyme hydrolysis or through differential use of the available $\mathrm{F}$ and B cells. However, on longer time scales ( $>48 \mathrm{~h})$, acclimation could conceivably result from either an increase in the number of F- and B-cells, or an increase in the concentration of enzyme per cell, or both. Thus short- and medium-term acclimation are likely to proceed at the cellular level via different sets of regulatory factors (Mayzaud 1986) and the two are not directly comparable.

Experiments to test the validity of ETS activity as an estimator of respiratory rates carried out by Båmstedt (1980) and Ikeda \& Skjoldal (1980) both showed a fair correspondence between the 2 measurements despite some differences in the time scales for acclimation. Fast decreases in ETS activity and respiration rates for either fed or starved Acartia were reported in the same 2 studies, with strong indications that the effect of feeding conditions was additive to another unknown underlying effect. The results of the present study confirm these observations and suggest a laboratory-effect-related food limitation which was only released (Expt 4) when feeding at saturation occurred. In contrast, GDH activity seemed more influenced by such an effect as it never recovered to a level close to the natural one.

Correspondence between intermediary metabolism (respiration and/or nitrogen excretion) and digestive enzyme activity has been proposed from comparisons of different copepod species living in the same environment (Gaudy \& Boucher 1983), and postulated from observations of variations in ETS activity during studies of diel changes (Harris \& Malej 1986, Båmstedt 1988). Except during starvation, day-to-day patterns of ETS and GDH activities in the present experiments failed to covary with food quantity, although ETS activity appeared to be influenced by food quality (protein versus carbohyrate dominated) and food type (chrysophyte versus diatom). Under our experimental conditions, such independence from food concentration was to be expected, for several recent studies have indicated saturation of respiration rates may occur above food levels of $500 \mu \mathrm{gC}^{-1}$, in species as different as the copepod Acartia tonsa (Kiørboe et al. 1985) and the cladoceran Daphnia magna (Lampert 1986). Because of this, the increase in ETS activity which occurred in our Expt 4 when A. clausi were fed on an extremely strong pulse of Hymenomonas elongata was surprising, although obviously tied to the increase in specific dynamic action associated to the increase in ingestion rate. Moreover, why we observe a 'memory effect' after these copepods were transferred back to lower food levels is unclear, but could be related to the same regulatory processes that maintained high glycosidase activities under decreasing food concentrations in Expt 2.
The overall time stability of the both ETS and GDH in most our experiments is also an index of normal physiological behaviour, despite high food concentrations and high animal densities. Indeed, Båmstedt (1980) found no influence of Acartia tonsa densities between 15 and 800 ind. $1^{-1}$ and observed an increase in ETS activity from 1200 to $4000 \mathrm{ind} . \mathrm{1}^{-1}$. Stress situations such as copper poisoning (Båmstedt 1980) or high noise (vibrations) levels (Regnault \& Lagardère 1983) also resulted in an increase in either metabolic (respiration, ammonia excretion) or ETS levels.

As recently noted by Donaghay (1988), it would be useful to review the definition of time acclimation given by Mayzaud \& Poulet (1978) in order to emphasize: (1) that nutrition in copepods is controlled by feed-back mechanisms which operate to meet the metabolic requirements of individuals, and (2) that acclimation of the different aspects of nutrition (ingestion, digestion, assimilation), when necessary, may operate on different time scales. The influences of food quality, feeding history or food selectivity on ingestion rates are all evidence of feed-back controls. Whether they occur systematically with digestive acclimation is doubtful but both processes are part of a general adaptive strategy to a fluctuating trophic environment.

Acknowledgements. The authors thank Dr R. J. Conover for his helpful criticisms and comments of the manuscript. This research was supported by ERA-CNRS 228, NSERC grant \#3667 and FCAR team grant \#3578 to P. M. D.C. Biggs' participation was made possible by a Faculty Academic Study Leave Award from Texas A \& M University, supplemented by a TAMU minigrant for International Enhancement. We thank Mrs Laura Cassiani who performed most of the measurements on the biochemical composition of the phytoplankton cultures.

\section{LITERATURE CITED}

Arnaud, J., Brunet, M., Mazza, J. (1978). Studies on the midgut of Centropages typicus (copepod, calanoid). Cell Tissue Res. 187: 333-353

Arnaud, J., Brunet, M., Mazza, J. (1980). Structure et ultrastructure comparée de l'intestin chez plusieurs espèces de copépodes calanoides. Zoomorphologie 95: 213-333

Arnaud, J., Brunet, M., Mazza, J. (1983). Détection d'une activité phosphatasique acide dans les cellules B de l'intestin moyen de Centropages typicus (Copépode, calanoide). C. R. Acad. Sci. Paris 296: 727-730

Arnaud, J., Brunet, M., Mazza, J. (1984a). Détection d'une activité arylsulfatasique dans les cellules B de l'intestin moyen de Centropages typicus (Copépode, calanoide). C. R. Acad. Sci. Paris 298: 499-502

Arnaud, J., Brunet, M., Mazza, J. (1984b). Cytochemical detection of phosphatase and arylsulfatase in the midgut of Centropages typicus (Copepod, calanoid). Bas. appl. Histochem. 28: 399-412

Ayukai, T. (1987). Feeding by the planktonic calanoid copepod Acartia clausi, Giesbrecht, on natural suspended particulate matter of varying quantity and quality. J. exp. mar. Biol. Ecol. 106: 137-149 
Båmstedt, U. (1980). ETS activity as an estimator of respiratory rate of zooplankton populations. The significance of variations in environmental factors. J. exp. mar. Biol. Ecol. 42: 267-283

Båmstedt, U. (1984). Diel variations in the nutritional physiology of Calanus glacialis from lat. $78^{\circ} \mathrm{N}$ in the summer. Mar. Biol. 79: 257-267

Båmstedt, U. (1988). Interspecific, seasonal and diel variations in zooplankton trypsin and amylase activity in Kosterfjorden, western Sweden. Mar. Ecol. Prog. Ser. 44: 15-24

Bidigare, R. R., King, F. D., Biggs, D. C. (1982). Glutamate dehydrogenase (GDH) and respiratory electron-transport system (ETS) activities in Gulf of Mexico zooplankton. J. Plankton Res. 4: 895-911

Boucher, J., Samain, J.-F. (1974). L'activité amylasique indice de la nutrition du zooplancton; mise en évidence d'un rythme quotidien en zone d'upwelling. Tethys 6: 179-188

Boucher, J., Laurec, A., Samain, J.-F., Smith, S. L. (1976). Étude de la nutrition du zooplancton en zone d'upwelling par la mesure des activités enzymatiques digestives. In: Personne, G., Jaspers, H. (eds.) Proc. 10th Eur. Mar. Biol. Symp., Vol. II. University Press, Wetteren, p. 85-110

Conover, R. J. (1978). Transformation of organic matter. In: Kinne, O. (ed.) Marine ecology, Vol. IV, Dynamics. Wiley, Chichester, p. 221-499

Conover, R. J., Mayzaud, P. (1984). Utilization of phytoplankton by zooplankton during the spring bloom in a Nova Scotia inlet. Can. J. Fish. Aquat. Sci. 41: 232-244

Cowles, T. J., Olson, R. J., Chisholm, S. W. (1988). Food selection by copepods: discrimination on the basis of food quality. Mar. Biol. 100: 41-49

Cox, J. L. (1981). Laminarinase induction in marine zooplankton and its variability in zooplankton samples. J. Plankton Res. 3: 345-356

Cox, J. L., Willasson, S. W. (1981). Laminarinase induction in Calanus pacificus. Mar. Biol. Lett. 2: 307-311

Donaghay, P. L. (1988). The role of temporal scales of acclimation, food quality and trophic dominance in controlling the evolution of copepod feeding behavior. Bull. mar. Sci. 43: 469-485

Dubois, M., Gilles, K. A., Hamilton, J. K., Rebers, P. A., Smith, F. (1956). Colorimetric method for the determination of sugars and related substances. Analyt. Chem. 28: 350-356

Frost, B. W. (1972). Effect of size and concentration of food particles on the feeding behavior of the marine planktonic copepod Calanus pacificus. Limnol. Oceanogr. 17: 805-815

Gaudy, R., Boucher, J. (1983). Relation between respiration, excretion (ammonia and inorganic phosphorus) and activity of amylase and trypsin in different species of pelagic copepods from an Indian ocean equatorial area. Mar. Biol. 75: $37-45$

Harris, R. P., Malej, A. (1986). Diel patterns of ammonium excretion and grazing rhythms in Calanus helgolandicus in surface stratified waters. Mar. Ecol. Prog. Ser. 31: 75-85

Harris, R. P., Samain, J.-F., Moal, J., Martin-Jezequel, V., Poulet, S. A. (1986). Effect of algal diet on digestive enzyme activity in Calanus helgolandicus. Mar. Biol. 90: 353-361

Hassett, R. P., Landry, M. R. (1983). Effect of food level acclimation on digestive enzyme activities and feeding behavior of Calanus pacificus. Mar. Biol. 75: 47-55

Hassett, R. P., Landry, M. R. (1988). Short term changes in feeding and digestion by the copepod Calanus pacificus. Mar. Biol. 99: 63-74

Head, E. J. H., Conover, R. J. (1983). Induction of digestive enzyme in Calanus hyperboreus. Mar. Biol. Lett. 4: 219-231

Hirche, H. J. (1981). Digestive enzymes of copepodites and adults of Calanus finmarchicus and Calanus helgolandicus in relation to particulate matter. Kieler Meeresforsch. Sonderh. 5: 174-185

Huntley, M. (1981). Non-selective, non-saturating feeding by three calanoid copepod species of the Labrador Sea. Limnol. Oceanogr. 26: 831-842

Ikeda, T., Skjoldal, H. R. (1980). The effect of laboratory conditions on the extrapolation of experimental measurements to the ecology of marine plankton. VI. Changes in physiological activities and biochemical components of Acetes sibogae and Acartia australis after capture. Mar. Biol. 58: 285-293

Kiørboe, T., Mølenberg, F., Hamburger, K. (1985). Bioenergetics of the planktonic copepod Acartia tonsa: relation between feeding, egg production and respiration, and composition of specific dynamic action. Mar. Ecol. Prog. Ser. 26: 85-97

Koeller, P. A., Barwell-Clarke, J. E., Whitney, F., Takahashi, M. (1979). Winter conditions of marine zooplankton population in Saanich inlet, B.C., Canada. 3. Mesozooplankton. J. exp. mar. Biol. Ecol. 37: 161-174

Lampert, W. (1986). Response of the respiratory rate of Daphnia magna to changing food conditions. Oecologia (Berl.) 70: $495-501$

Landry, M. R., Hassett, R. P. (1985). Time scales in behavioral biochemical and energetic adaptations to food-limiting conditions by a marine copepod. Arch. Hydrobiol. Beih. Ergebn. Limnol. 21: 209-221

Libourel-Houde, S. E., Roman, M. R. (1987). Effects of food quality on the functional ingestion response of the copepod Acartia tonsa. Mar. Ecol. Prog. Ser. 40: 60-77

Lowry, O. H., Rosenbrough, N. J., Farr, A. L., Randall, R. J. (1951). Protein measurement with the Folin-phenol reagent. J. biol. chem. 193: 265-275

Mayzaud, P. (1980). Some sources of variability in the determination of digestive enzyme activity in zooplankton. Can. J. Fish. Aquat. Sci. 37: 1426-1432

Mayzaud, P. (1986). Digestive enzymes and their relation to nutrition. In: Corner, E. D. S., O'Hara, S. C. M. (eds.) The biological chemistry of marine copepods. Clarendon Press, Oxford, p. 165-225

Mayzaud, P., Farber-Lorda, J., Corre, M. C. (1985). Aspects of the nutritional metabolism of two Antarctic euphausiids Euphausia superba and Tysanoessa macrura. In: Siegfried, W. R., Condy, P. R., Laws, R. M. (eds.) Antarctic nutrient cycles and food webs. Springer-Verlag, Berlin, p. 330-338

Mayzaud, P., Mayzaud, O. (1981). Kinetic properties of digestive carbohydrases and proteases of zooplankton. Can. J. Fish. Aquat. Sci. 38: 535-543

Mayzaud, P., Mayzaud, O. (1985). The influence of food limitation on the nutritional adaptation of marine zooplankton. Arch. Hydrobiol. Beih. Ergebn. Limnol. 21: 223-233

Mayzaud, O., Mayzaud, P., de la Bigne, C., Grohan, P., Conover, R. J. (1984). Diel changes in the particulate environment, feeding activity and digestive enzyme concentration in neritic zooplankton. J. exp. mar. Biol. Ecol. 84: 15-35

Mohanna-Al, S. Y., Nott, J. A., Lane, D. J. W. (1985). Mitotic Eand secretary F-cells in the hepatopancreas of the shrimp Penaeus semisulcatus (Crustacea, decapoda). J. mar. biol. Ass. U.K. 65: 901-910

Nott, J. A., Corner, E. D. S., Marin, L. J., O'Hara, S. C. M. (1985). Cyclical contributions of the digestive epithelium to fecal pellet formation by the copepod Calanus helgolandicus. Mar. Biol. 83: 271-280

O'Connors, H. B., Small, L. F., Donaghay, P. L. (1976). Particlesize modification by two size classes of the estuarine copepod Acartia clausi. Limnol. Oceanogr. 21: 300-308 
Paffenhöfer, G. A., Van Sant, K. B. (1985). The feeding response of a marine planktonic copepod to quantity and quality of particles. Mar. Ecol. Prog. Ser. 27: 55-65

Reeve, M. R., Walter, M. A. (1977). Observations on the existence of lower threshold and upper critical food concentrations for the copepod Acartia clausi. J. exp. mar. Biol. Ecol. 29: 211-221

Regnault, M., Lagardère, J. P. (1983). Effects of ambient noise on the metabolic level of Crangon crangon (Decapoda, natantia). Mar. Ecol. Prog. Ser. 11: 71-78

Roche-Mayzaud, O. (1985). Purification and kinetic properties of the $\alpha$-amylase from the copepod Acartia clausi (Giesbrecht). Comp. Biochem. Physiol. 82B: 725-730

Roche-Mayzaud, O., Mayzaud, P. (1987). Purification of endo and exolaminarinase and partial characterization of the exoacting form from the copepod Acartia clausi (Giesbrecht). Comp. Biochem. Physiol. 88B: 105-110

Samain, J.-F., Moal, J., Daniel, J. Y., Le Coz, J. R. (1981).

This article was presented by Dr R. J. Conover, Dartmouth, N.S., Canada
Possible processes of nutritive adaptations for zooplankton: a demonstration on Artemia. Kieler Meeresforsch. Sonderh. 5: 218-228

Tande, K. S., Slagstadt, D. (1982). Ecological investigation on the zooplankton community of Balsfjorden, northern Norway. Seasonal and short-time variations in enzyme activity in copepodite Stage V and VI male and female of Calanus finmarchicus. Sarsia 67: 63-68

Uye, S., Kasahara, S. (1983). Grazing of various developmental sages of Pseudodiaptomus marinus (Copepode, calanoida) on naturally occurring particles. Bull. Plankton Soc. Japan 30: 147-158

Van Wormhoudt, A. (1973). Activité des protéases, des amylases et des protéines solubles au cours du développement larvaire chez Palaemon serratus. Mar. Biol. 19: 245-258

Yentsch, C. S., Menzel, D. (1963). A method for the determination of phytoplankton chlorophyll and phaeophytin by fluorescence. Deep Sea Res. 10: 221-231

Manuscript first received: January 8, 1990 Revised version accepted: October 10, 1990 